\title{
Study of Factors Associated with Anemia among Women in Reproductive Age in Kolda (Senegal)
}

\author{
Tine Jean Augustin Diégane, Faye Adama, Diop Sophie, Niang Khadim, Bassoum Oumar, \\ Leye Mamadou Moustapha Mbacke, Sougou Ndeye Mareme, Diongue Fatoumata Bintou, \\ Diallo Amadou Ibra, Diongue Mayassine, Camara Maty Diagne, Dankoko Boubacar, \\ Seck Ibrahima, Dia Anta Tal
}

Department of Preventive Medicine and Public Health of the Cheikh Anta Diop University of Dakar (UCAD), Institut de Sante et Developpement (ISED), UCAD, Dakar, Senegal

Email: leki105@yahoo.fr, diegantin@gmail.com

How to cite this paper: Jean Augustin Diégane, T., Adama, F., Sophie, D., Khadim, N., Oumar, B., Mamadou Moustapha Mbacke, L., Ndeye Mareme, S., Fatoumata Bintou, D., Amadou Ibra, D., Mayassine, D., Maty Diagne, C., Boubacar, D., Ibrahima, S. and Anta Tal, D. (2018) Study of Factors Associated with Anemia among Women in Reproductive Age in Kolda (Senegal). Open Journal of Obstetrics and Gynecology, 8, 688-699.

https://doi.org/10.4236/ojog.2018.87073

Received: May 10, 2018

Accepted: June 25, 2018

Published: June 28, 2018

Copyright $\odot 2018$ by authors and Scientific Research Publishing Inc. This work is licensed under the Creative Commons Attribution International License (CC BY 4.0).

http://creativecommons.org/licenses/by/4.0/

c) (i) Open Access

\begin{abstract}
Introduction: Anemia in women of reproductive age is a common health problem in the region of Kolda (Senegal). The objective of this research was to study the risk factors of anemia among women in reproductive age in Kolda (Senegal). Methodology: A cross-sectional, descriptive and analytical study of women in reproductive age and their households was conducted in the Kolda region between October and December 2015. This was a three-stage random sample survey. The data was collected during an individual interview. Logistic regression was used to identify the factors of this anemia. Results: In this study, 968 women of reproductive age were surveyed. The average age of women was 27 years with a standard deviation of 7.4 years. There were $10 \%$ of pregnant women, $36.3 \%$ of lactating women and $53.7 \%$ of women neither pregnant nor lactating. The average size of the households surveyed was 14 people and the $36.3 \%$ had an average economic level. The majority of households were equipped with traditional latrines $(76.9 \%)$. Women were neither pregnant nor lactating in $53.7 \%$, were uneducated in $70.7 \%$ and $81 \%$ used micronutrient-rich foods. The prevalence of anemic women was $55.2 \%$. The factors associated with anemia in women in Kolda were the use of traditional latrines $(\mathrm{ORa}=1.48[1.0-2.1])$, the woman's pregnancy status $(\mathrm{ORa}=5[2.7-$ $9.8])$, non-education of the woman $(\mathrm{ORa}=1.52[1.1-2.0])$, the existence of income-generating activity for the woman $(\mathrm{ORa}=0.69[0.5-0.9])$, the processing of local products in the household $(\mathrm{ORa}=0.5[0.3-0.9])$ and the use of at least one micronutrient rich food in the household (ORa $=0.73$ [0.49 - 1.0]). Conclusion: The prevalence of anemia among women in reproductive age is still high in the Kolda region. To combat this phenomenon, awareness campaigns on iron and folic acid supplementation should be stepped up, the use of modern latrines should be promoted and the empo-
\end{abstract}


werment of women should be strengthened.

\section{Keywords}

Anemia, Woman, Risk Factors, Kolda, Senegal

\section{Introduction}

Anemia is a real public health problem in our developing countries. According to World Health Organization (WHO), in 2014, an estimated 1.62 billion people worldwide suffer from anemia. Children and women of childbearing age are unfortunately the most exposed, with a global prevalence of $43 \%$ in children under five, $38 \%$ in pregnant women and $29 \%$ in non-pregnant women aged 15 to 49 years [1] [2].

In Senegal, according to EDS-MICS 2010-2011, the prevalence of anemia among women is $54 \%$ compared to $31 \%$ among men. Kolda had a percentage of women anemic at $55.8 \%$ [3].

The consequences of anemia on the health are multiple. Anemia decreases physical capacity, causes a state of weakness, fatigue, affects the feeling of well-being. It reduces intellectual performance and work capacity thus slowing down productivity. In addition, it reduces the resistance to infections and increases the risk of death during the gravid-puerperal period, resulting in health expenses that could have been avoided. In short, it has major negative consequences for human health and social and economic development [4] [5] [6] [7].

The health sector is one of the priorities of Senegal. This is evidenced by the increase in the ministry's budget (29 billion in 2000 to 108.4 billion in 2010) and by the objectives set in the PNDS 2009-2018. Despite all efforts, anemia remains a public health problem more for women and children under 5 years [3]. The Kolda region is one of the most affected regions.

This study contributes to the fight against maternal and infant mortality and morbidity. It aims to study the risk factors associated with anemia in women of childbearing age in Kolda.

\section{Materials and Methods}

\subsection{Framework of the Study}

This was carried out in the Kolda region which is located in southern Senegal. This region covers $13,721 \mathrm{~km}^{2}$, with a population of 748,451 inhabitants of which $43.7 \%$ are women. The number of women of reproductive age is 58,589 women. Administratively, the region of Kolda is composed of the departments of Kolda, Medina Yoro Foula and Vélingara [8]. This region is predominantly rural and is among the most disadvantaged regions of Senegal. According to the results by region of EDS-MICS 2010-2011, indicators of maternal and child 
health are worrying. The mortality rate of children under 5 years in Kolda is $154 \%$ against $72 \%$ in Senegal. The prevalence of Kolda chronic malnutrition is $24 \%$ against $16.5 \%$ in Senegal. Only $36.6 \%$ of the population in Kolda have access to basic social and health services. The lack of resources available to support the most vulnerable groups, especially women, are factors contributing to this situation and to the deterioration of the living conditions of the poorest [3].

\subsection{Type of Study}

It is a cross-sectional, descriptive and analytical study. It was made between October and December 2015.

\subsection{Study Population and Sampling}

This study concerned all women of reproductive age. Included were all women aged 15 to 45 living in the Kolda region and having freely accepted to participate in the study. The sample size was calculated from the adjusted Schwartz formula. It was appreciated based on the prevalence of iron deficiency in women published in the EDS-MICS 2010-2011 which was 54\% and a proportion of non-respondents of $5 \%$. Schwartz's formula is as follows: $\mathrm{n}=\left(\varepsilon \alpha^{2}, \mathrm{pq}\right) / \mathrm{i}^{2}$ with $\varepsilon \alpha$ $=1.96$ : reduced deviation corresponding to the risk accepted $(\alpha=5 \%, \varepsilon \alpha=1.96)$; $\mathrm{p}=$ prevalence of anemia in women $=54 \%$; : complement of $\mathrm{p}=1-\mathrm{p}$; i: accuracy $=4 \% ; \mathrm{n}=$ sample size; $\mathrm{N}=\mathrm{n}+5 \%(\mathrm{n})=$ number of women to be surveyed by health district.

The sample size that maximizes the estimates is 320 women per department. In total, the sample size is 960 individuals for the three departments. For the choice of statistical units, a three-stage random survey was carried out. From the National Agency for Statistics and Demography (ANSD) census database, 16 census districts (CDs) were randomly selected by department. In each CD, 20 concessions were drawn from the census base. Finally, in each concession, the enumerator had identified all the eligible women and from this list, he selected a woman from 15 to 45 years old. In choosing women, he respected the proportionality of two pregnant women, six lactating women and twelve women who were neither pregnant nor breastfeeding. This proportionality was derived from the report on maternal status of women in Senegal of EDS-MICS 2010-2011 [3].

\subsection{Data Collection}

The data collection was done on the basis of electronic series of question made on the CSpro software. The investigators were responsible for collecting the data directly on the tablets. They were organized into 18 teams of four investigators and one supervisor per department. After four days of training, the investigators conducted a pilot survey to test the questionnaires and masks before starting the actual collection. The measurement of anemia was made by hemoglobinemia which was determined by the HemoCue@ device. It is a portable hemoglobinometer 
used to quantify the hemoglobin level of the person in less than a minute, from a drop of capillary blood. The woman is considered anemic if the hemoglobin is less than $11 \mathrm{~g} / \mathrm{dl}$. For pregnant women, anemia will be considered mild if the hemoglobin level is between 10.0 and $10.9 \mathrm{~g} / \mathrm{dl}$ [3]. As in the 2010-2011 EDS-MICS of Senegal, anemia levels were set at the following intervals [9]:

- Severe anemia $=$ hemoglobinemia $<7 \mathrm{~g} / \mathrm{dl}$,

- Moderate anemia $=7 \mathrm{~g} / \mathrm{dl} \leq$ hemoglobinemia $<10 \mathrm{~g} / \mathrm{dl}$,

- Mild anemia $=10 \mathrm{~g} / \mathrm{dl} \leq$ hemoglobinemia $<11 \mathrm{~g} / \mathrm{dl}$

The data collected focused on:

- the characteristics of the woman such as maternal state, education, autonomy, level of knowledge, attitudes and practices in nutrition;

- and information on household characteristics such as marital status, ethnicity, availability of resources, socio-economic level, household size and availability of modern latrines.

\subsection{Data Analysis}

The data were analyzed with software $\mathrm{R}$. The qualitative variables were described with absolute and relative frequencies and the quantitative variables by mean and standard deviation. Bivariate tests were made using Chi-square for comparison of proportions, Student or ANOVA for comparison of means. When parametric test conditions were not observed, Kruskall Wallis non-parametric tests or Fisher's exact test were used. A multivariate analysis was performed with a simple logistic regression for the determination of anemia-related factors, with an adjustment to the independent variables while ensuring the applicability conditions with a significance threshold set at $5 \%$. Variables with $\mathrm{p}$ less than 0.25 in bivariate analysis were used for modeling [10]. The lrtest (likelihood ratio) and AIC allowed the choice of the latter with the step-down method. Finally, the Hosmer Lemeshow test made it possible to test the adequacy of the final model [11]. Associations were measured by odds ratios with their confidence intervals.

\subsection{Ethical Considerations}

The approval of the National Ethics Committee for Health Research (CNERS) of Senegal was obtained before the start of field activities. Participation in this study was free. Free and informed consent was obtained from all women aged 18 and over. For women under the age of 18 , consent of their legal guardian was obtained before their own consent. An information sheet was administered to each woman (and the legal guardian for minors), before signing the consent form. No compensation or compensation was given to the people surveyed. Women who have been diagnosed with anemia have been referred to the health center closest to home for treatment and follow-up. The collected data was personal. The identification of people who agreed to take part was not mentioned on the tools collection. Wherever the results are used, the anonymity has been 
respected.

\section{Results}

\subsection{Women' Reproductive Age Characteristics}

In all, 968 women of reproductive age were surveyed. The average age of women was 27 years with a standard deviation of 7.4 years. There were $10 \%$ of pregnant women, $36.3 \%$ of lactating women and $53.7 \%$ of women neither pregnant nor lactating. The majority of women were uneducated with a frequency of $70.7 \%$. The study also showed that $28.3 \%$ of women had an income-generating activity (IGA). Only $4.4 \%$ of women had a bank account and $40.9 \%$ were members of a for-profit association. Women had poor knowledge of the anti-anemia products of pregnancy (68.9\%) and good culinary practices $(63.3 \%)$ and hygienic practices (31.3\%). Only $8.9 \%$ used enriched flour in their culinary preparations. Regarding hygiene, $47.8 \%$ of women had a bad hand washing attitude (see Table 1 ).

\subsection{Characteristic of the Households Women Surveyed}

The majority of women lived in rural areas (72\%) with households of more than 6 persons (83.9\%). Monogamous brides represented 51.8\%. The economic level was poor in $29.8 \%$ of households. The major ethnic group was Al-Poular with $73.3 \%$. The means of processing local products were not readily available. Only $28.1 \%$ of households had access to irrigated parcels. The percentage of families with modern latrines was only $16.4 \%$. The majority of families had access to a source of drinking water within one kilometer (89.6\%) (see Table 2).

\subsection{Anemia in Women of Reproductive Age}

The study showed that $55.2 \%$ (or 534 women) of the women surveyed in the Kolda region are anemic. Of these anemic women, $12.2 \%$ had severe anemia and $51 \%$ had moderate anemia (see Figure 1)

\subsection{Risk Factors Associated with Anemia in Women of Reproductive Age in Kolda}

Logistic modeling has found factors related household-such as large family extent and the use of traditional latrines ( $\mathrm{OR}=1.48[1.0-2.1])$. The pregnant woman was five times risquer than the nursing one $(\mathrm{OR}=5[2.7-9.8])$. The lack of education of women was a factor of exposure to anemia $(\mathrm{OR}=1.52$ [1.1 $2.0])$. Processing of local products $(\mathrm{OR}=0.5[0.3-0.9])$ is a protective factor against the onset of anemia in women of reproductive age in Kolda (see Table 3).

\section{Discussion}

Anemia is a major risk of maternal mortality in developing countries. This study allowed us to estimate the prevalence of anemia of women in Kolda region through the use of hemoglobinometer. The main limitation of this study is that 
Table 1. Characteristics of the woman of reproductive age in Kolda.

\begin{tabular}{|c|c|c|c|}
\hline \multirow{2}{*}{\multicolumn{2}{|c|}{ Women's reproductive age characteristics }} & \multicolumn{2}{|c|}{ Frequencies } \\
\hline & & Absolute(n) & Relative\% \\
\hline \multirow{3}{*}{ Maternal state $(n=968)$} & Pregnant women & 97 & 10.0 \\
\hline & Lactating women & 351 & 36.3 \\
\hline & $\begin{array}{l}\text { Women Neither pregnant } \\
\text { Nor Lactating }\end{array}$ & 520 & 53.7 \\
\hline \multirow{2}{*}{ Instruction } & Educated & 284 & 29.3 \\
\hline & No educated & 684 & 70.7 \\
\hline \multirow{2}{*}{$\begin{array}{l}\text { Share of household expenditure } \\
\text { controlled by women }\end{array}$} & $\begin{array}{l}\text { Woman controling less } \\
\text { than } 50 \% \text { of the spents }\end{array}$ & 777 & 80.3 \\
\hline & $\begin{array}{l}\text { women controling at least } \\
50 \% \text { of the spents }\end{array}$ & 191 & 19.7 \\
\hline \multirow{2}{*}{ Income generating activity } & yes & 274 & 28.3 \\
\hline & No & 694 & 71.7 \\
\hline \multirow{2}{*}{ Bank account } & yes & 42 & 4.4 \\
\hline & No & 926 & 95.6 \\
\hline \multirow{3}{*}{$\begin{array}{l}\text { Members of women profit making } \\
\text { association }\end{array}$} & yes & 396 & 40.9 \\
\hline & No & 572 & 59.1 \\
\hline & good & 67 & 6.9 \\
\hline \multirow[t]{3}{*}{$\begin{array}{l}\text { Knowledge of antianaemic of preg- } \\
\text { nancy }\end{array}$} & fair & 234 & 24,2 \\
\hline & weak & 667 & 68.9 \\
\hline & good & 155 & 16 \\
\hline \multirow[t]{3}{*}{$\begin{array}{l}\text { Knowledge about nutritional } \\
\text { practices }\end{array}$} & fair & 562 & 58.1 \\
\hline & good & 251 & 25.9 \\
\hline & Bon & 155 & 16 \\
\hline \multirow[t]{3}{*}{$\begin{array}{c}\text { Knowledge about good hygiene } \\
\text { practices }\end{array}$} & fair & 510 & 52.7 \\
\hline & weak & 303 & 31.3 \\
\hline & good & 11 & 1.1 \\
\hline \multirow[t]{2}{*}{ Knowledge about culinary attitudes } & fair & 344 & 35.6 \\
\hline & weak & 613 & 63.3 \\
\hline \multirow{2}{*}{$\begin{array}{l}\text { Use of enriched flours in culinary } \\
\text { practice }\end{array}$} & yes & 86 & 8.9 \\
\hline & No & 882 & 91.1 \\
\hline \multirow{2}{*}{ Local product transformation } & yes & 62 & 6.4 \\
\hline & No & 906 & 93.6 \\
\hline \multirow{3}{*}{$\begin{array}{l}\text { Using at least one food rich in } \\
\text { micronutrient }\end{array}$} & yes & 784 & 81 \\
\hline & No & 184 & 19 \\
\hline & bad attitudes & 463 & 47.8 \\
\hline \multirow[t]{2}{*}{ Washing hands attitudes } & acceptable attitudes & 374 & 38.7 \\
\hline & good attitudes & 131 & 13.5 \\
\hline
\end{tabular}


Table 2. Household characteristics of women surveyed in Kolda.

\begin{tabular}{|c|c|c|c|}
\hline \multirow{2}{*}{\multicolumn{2}{|c|}{ Household Characteristics }} & \multicolumn{2}{|c|}{ Frequencies } \\
\hline & & Absolute(n) & Relative \% \\
\hline \multirow{2}{*}{ Social Environment } & Rural & 698 & 72 \\
\hline & Urban & 270 & 28 \\
\hline \multirow{2}{*}{ Size of the families } & $>6$ persons & 812 & 8.9 \\
\hline & $\leq 6$ persons & 156 & 16.1 \\
\hline \multirow{4}{*}{ Matrimonial situation } & Monogame & 502 & 51.8 \\
\hline & Polygame & 445 & 46 \\
\hline & Divorcees or Widows & 19 & 2 \\
\hline & Unmarried & 2 & 0.2 \\
\hline \multirow{4}{*}{ Ethnic group } & Al-Poular & 710 & 73.3 \\
\hline & Ouolofs & 125 & 12.9 \\
\hline & Mandingue & 85 & 8.8 \\
\hline & Minority Ethnic group & 48 & 5 \\
\hline \multirow{5}{*}{ Position of economic welfare } & Very riche & 30 & 3.1 \\
\hline & Riche & 104 & 10.7 \\
\hline & Average & 351 & 36.3 \\
\hline & Poor & 288 & 29.8 \\
\hline & Very poor & 195 & 20.1 \\
\hline \multirow{2}{*}{ Availability of irrigated parcels } & yes & 273 & 28.2 \\
\hline & No & 695 & 71.8 \\
\hline \multirow{2}{*}{$\begin{array}{l}\text { Availability of transformation's } \\
\text { means of the local products }\end{array}$} & yes & 247 & 25.5 \\
\hline & No & 721 & 74.5 \\
\hline \multirow{2}{*}{ Accessible to drinking water } & $<1 \mathrm{~km}$ & 867 & 89.6 \\
\hline & $\geq 1 \mathrm{~km}$ & 101 & 10.4 \\
\hline \multirow{2}{*}{ Treatment of water drink } & yes & 805 & 83.2 \\
\hline & No & 163 & 16.8 \\
\hline \multirow{2}{*}{$\begin{array}{l}\text { Availability of latrines in the } \\
\text { concession }\end{array}$} & Traditional & 809 & 83.6 \\
\hline & Modern latrines & 159 & 16.4 \\
\hline
\end{tabular}

Table 3. Factors associated with anemia of women of reproductive age in Kolda (by logistic regression).

\begin{tabular}{|c|c|c|c|}
\hline Variables & ORajusted & IC $95 \%$ & pvalue \\
\hline \multicolumn{4}{|c|}{ Characteristics of the family } \\
\hline \multicolumn{4}{|c|}{ Lenght of the family } \\
\hline$\leq 6$ persons & - & 1 & \\
\hline$>6$ persons & 1.44 & {$[0.9-2.1]$} & 0.07 \\
\hline \multicolumn{4}{|c|}{ Types of latrines } \\
\hline
\end{tabular}




\section{Continued}

\begin{tabular}{|c|c|c|c|}
\hline Modernes & - & 1 & \\
\hline Traditionnals & 1.48 & {$[1.0-2.1]$} & 0.03 \\
\hline \multicolumn{4}{|c|}{ Woman characteristic } \\
\hline \multicolumn{4}{|c|}{ Maternal state } \\
\hline Breast feeding women & - & 1 & \\
\hline Pregnant women & 5.0 & {$[2.7-9.8]$} & $<0.0001$ \\
\hline $\begin{array}{l}\text { Neither pregnant nor breast } \\
\text { feeding woman }\end{array}$ & 0.86 & {$[0.6-1.1]$} & 0.33 \\
\hline \multicolumn{4}{|c|}{ Instruction level } \\
\hline educated & - & 1 & \\
\hline No educated & 1.52 & {$[1.1-2.0]$} & 0.008 \\
\hline \multicolumn{4}{|c|}{ Incomegeneratingactivy } \\
\hline No & - & 1 & \\
\hline yes & 0.69 & {$[0.5-0.9]$} & 0.02 \\
\hline \multicolumn{4}{|c|}{ Local product transformation } \\
\hline No & - & 1 & \\
\hline yes & 0.5 & {$[0.3-0.9]$} & 0.04 \\
\hline \multicolumn{4}{|c|}{ Using at least one Food rich in micronutrient } \\
\hline No & - & 1 & \\
\hline yes & 0.73 & {$[0.49-1.0]$} & 0.11 \\
\hline
\end{tabular}

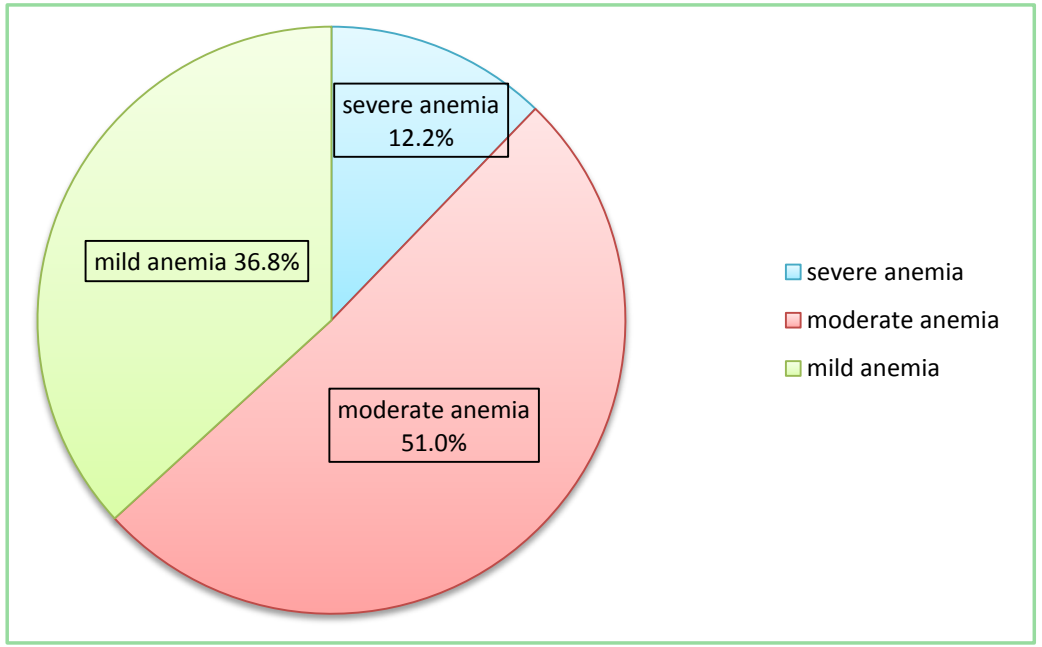

Figure 1. Distribution of anemic women by level of severity $(\mathrm{N}=534)$.

the cause of anemia has not been sought. The prevalence of anemia among women of reproductive age in the Kolda region is $55.2 \%$ (or 534 women), $51 \%$ with moderate anemia, $36.8 \%$ with mild anemia and $12.2 \%$ with severe anemia. It reaches $83.5 \%$ of pregnant women and $55 \%$ of breastfeeding women. According to the ongoing EDS 2010-2011, in Senegal, the prevalence of anemia among 
women is $54 \%$, of which $61 \%$ among pregnant women $49 \%$ among those who are breastfeeding [3]. Overall, $49 \%$ of women in Guinea Conakry suffer from anemia, $65 \%$ of pregnant women and $52 \%$ of breastfeeding women [12]. In Côte d'Ivoire, the EDS-MICS 2011-2012, recorded 54\% of anemic women, $64 \%$ of pregnant women, and 55\% of breastfeeding women [13]. Indeed, the Vitamin and Mineral Nutrition Information System (VMNIS) classifies the prevalence of anemia greater than or equal to $40 \%$ as severe [14]. This study found several risk factors for anemia in women of reproductive age in Kolda. Factors relate to the quality of family cleanness, the woman's maternal status, her level of autonomy and her nutritional attitudes and practices.

The presence of traditional latrines increases the occurrence of anemia. Women whose households have traditional latrines are 1.48 times more likely to suffer from anemia than those equipped with modern latrines. This result could be explained by the pathogenic effect of intestinal parasitosis, the transmission of which is particularly favored by defective hygiene, particularly the fecal danger. Unlike modern latrines, traditional latrines have a bad evacuation and hand washing system, which exposes them to intestinal parasitosis. Helminthiases are the most frequent parasitosis and increase the frequency and severity of anemia [15]. As a result, these women are at high risk of water-borne and unsanitary infections [16].

It has been found in Kolda that $83.5 \%$ of pregnant women are anemic. EDS-MICS 20102011 states that Senegalese pregnant women are more often anemic (61\%) than those who are breastfeeding (49\%) or those who are neither pregnant nor breastfeeding (56\%) [3]. According to the Bayebie study, $66.1 \%$ of pregnant women in the Dakar region have anemia [17]. The WHO estimated in 2015 worldwide that $43 \%$ of pregnant women were anemic compared to $33 \%$ of non-pregnant women [18]. Leke and Kremp noted that in Africa, $66.6 \%$ of pregnant women were anemic [19]. Miguel found that in Costa Rica, $60 \%$ of pregnant women are anemic [20]. In Kolda, the risk of anemia is multiplied by five in pregnant women. For Sharmanov, the prevalence of anemia was twice as high among pregnant women as among other women [16]. This high prevalence of anemia in pregnant women may have several explanations: iron and folic acid deficiency, the needs of which are increased with a diet that is not very diversified, and low female adherence to prenatal consultation (CPN) and supplementation programs, the lack of access to health facilities and the low decision-making power of women. Khadim et al. have shown that among pregnant women who are on iron and folic acid supplementation, only $56 \%$ are adhering to iron and folic acid for 90 days. The level of education and accessibility of CPN services were key factors in this uptake of iron and folic acid [21]. A good level of education of the woman would also protect against the occurrence of anemia in women. The proportion of educated and anemic women (48.9\%) differs from the proportion of uneducated and anemic (58.9\%). In Ivory Cost, anemia is more common among women with no education (55.3\%) than among those with primary (54.3\%) and secondary (48.8\%) [13]. 
This study showed that women with an income-generating activity (IGA) have fewer cases of anemia than those without an IGA. Income-generating activity appears to protect against anemia $(\mathrm{OR}=0.6[0.5-0.9])$. The financial autonomy of the woman increases her decision-making power over her medical follow-up. Jn 2006, Anorlu's study in Nigeria found that socio-economic status was significantly associated with anemia $(\mathrm{p}<0.0001)$ with higher prevalence among women of low socioeconomic status [22]. The survey in Mauritania revealed that the percentage of anemic subjects is slightly higher among women who do not work (50.2\%) than among women who work (46.8\%) [23]. In 2013, Bayebie in Dakar found that economic activity reduced the risk of anemia [17]. A good level of socio-economic well-being is a protective factor against anemia. According to EDS 2010-2011, the prevalence of anemia is 58\% for women in the poorest households against $53 \%$ for those of the richest households [3]. Anemia is therefore a health problem related to the socio-economic level of the countries. A good socio-economic level would be a protective factor against anemia through a better nutritional status.

The transformation of local products has a significant protective effect on the occurrence of anemia (OR $=0.5[0.3-0.9])$. In Senegal, diets are often based on cereals, roots and tubers that contain significant amounts of iron but also inhibitors of its absorption, especially phytates. Also, Senegalese dishes have a low bioavailability of iron, based on millet in villages and rice in cities [24]. Traditional practices such as dehulling cereals, soaking and fermentation increase the bioavailability of iron [25] [26]. The implementation of food fortification and diversification strategies is necessary to successfully cover the micronutrient intake of vulnerable populations.

\section{Conclusion}

Anemia is the most common abnormality in hematology. Clinical signs of anemia are inconsistent and may be associated with signs of tissue hypoxia (asthenia, dizziness, paleness, palpitations, dyspnea) and those related to compensatory mechanisms (tachycardia). It is a major public health problem particularly in developing countries and frequently affects women aged 15 to 49 . Kolda is a poor region with a low rate of urbanization, $72 \%$ of households are rural. The average household size is 14 people. This study showed that the prevalence of anemia of woman in reproductive age in the Kolda region is $55.2 \%$ (534 women), of which $51 \%$ had moderate anemia, $36.8 \%$ a mild anemia and $12.2 \%$ a severe anemia. The study showed that a good level of education, the existence of income-generating activity, the use of modern latrines and the use of local processing and enrichment methods are elements that should be promoted to combat the high prevalence of anemia in women of reproductive age and especially pregnant women. Interventions incorporating these factors should be implemented in the Kolda region in a multisectoral, multidisciplinary and at all levels of the health pyramid to combat the scourge of woman anemia. 


\section{Acknowledgements}

- Centre d'Excellence Africain pour la Santé de la mère et de l'enfant (CEASAMEF/UCAD).

- The Micronutrient Initiative.

- All women who agreed to participate in this survey.

\section{References}

[1] Branca, F., Mahya, L. and Shireen Mustafa, T. (2014) The Lack of Progress in Reducing Anaemia among Women: The Inconvenient Truth. Bulletin of the World Health Organization, 92, 231. https://doi.org/10.2471/BLT.14.137810

[2] Stevens, G.A., Finucane, M.M., De-Regil, L.M., Paciorek, C.J., Flaxman, S.R., Branca, F., et al. (2013) Global, Regional, and National Trends in Haemoglobin Concentration and Prevalence of Total and Severe Anaemia in Children and Pregnant and Non-Pregnant Women for 1995-2011: A Systematic Analysis of Population-Representative Data. The Lancet Global Health, 1, e16-e25.

https://doi.org/10.1016/S2214-109X(13)70001-9

[3] Agence Nationale de la Statistique et de la Démographie (ANSD) du Sénégal. Enquête démographique et de santé à indicateurs multiples-2010-2011-Rapport FINAL. Dakar, février 2012. https://dhsprogram.com/pubs/pdf/FR258/FR258.pdf

[4] WHO, UNICEF, UNFPA and the World Bank (2007) Maternal Mortality in 2005. Geneva, 16-18.

[5] Leslie, J. (1991) Women's Nutrition: The Key to Improving Family Nutrition in Developing Countries? Health Policy and Planning, 6, 1-19. https://doi.org/10.1093/heapol/6.1.1

[6] Lemonnitv, D. and Ingenblwk, C.I.Y. (1989) Nutritional Deficiencies in Developing Countries. Third Day of the GIRM. KARTHALA. ACCT, Paris, 280-284.

[7] Ayoubi, J.M., Hirt, R., Badiou, W., Hininger-Favier, I., Zraik-Ayoubi, F., Berrebi, A. and Pons, J.C. (2012) Nutrition and Pregnant Woman. EMC Obstetric Gynecology, 5-7.

[8] Agence Nationale de la Statistique et de la Démographie (ANSD) du Sénégal. Situation Économique et Sociale régionale de la région de Kolda - 2013. http://www.ansd.sn/

[9] DeMaeyer, E.M. (1989) Preventing and Controlling Iron Deficiency Anemia through Primary Health Care: A Guide for Health Administrators and Programme Managers. Genève.

[10] Collett, D. (2003) Modeling Binary Data. CRC Press, London, 387 p.

[11] Hosmer, D.W. and Lemeshow, S. (1989) Applied Logistic Regression. John Wiley, New York, 307 p.

[12] Ministère du Plan (2012) Enquête démographique et de Santé et à Indicateurs Multiples (EDS-MICS)-République de Guinée. Rapport Final, 196-197.

[13] Ministère de la Santé et de la Lutte contre le SIDA. Enquête démographique et de Santé et à Indicateurs Multiples-Côte d'Ivoire, 2011-2012. Rapport Final, 202-203.

[14] Benoist, B., et al. (2008) Worldwide Prevalence of Anaemia 1993-2005. WHO Global Database on Anaemia, Genève, Organisation mondiale de la Santé. http://apps.who.int/iris/bitstream/10665/43894/1/9789241596657_eng.pdf

[15] Kalenga, M.K., Nyembo, M.K., Nshimba, M. and Foidart, J.M. (2003) Etude de 
l'anémie chez les femmes enceintes et les femmes allaitantes de Lubumbashi (République Démocratique du Congo). Journal de Gynécologie Obstétrique et Biologie de la reproduction, 32, 647-653.

[16] Tiné, S.C. (2011) Facteurs d'agrégation de l'anémie dans les ménages au Cameroun 2011. Montréal, 178 p.

[17] Bayebié, B. (2013) Analyse des déterminants socioéconomiques de l'anémie ferriprive chez la femme enceinte au Sénégal: Cas de la région de Dakar. Economie de la santé, Dakar.

[18] (2014) Bulletin de l'Organisation mondiale de la Santé, 92, 231.

[19] Leke, L. and Kremp, D. (1989) Impact des carences nutritionnelles sur l'anémie de la femme enceinte. Développement et Santé, 84.

[20] Miguel, F.M.D. (1990) La femme enceinte et l'anémie. In: Mères et Enfants, La Nutrition Maternelle, Vol. 9.

[21] Niang, K., Faye, A., Tine, J.A.D., Diongue, F.B., Ndiaye, B., Ndiaye, M.B., Ndiaye, P. and Tal-Dia, A. (2017) Determinants of Iron Consumption among Pregnant Women in Southern Senegal. Open Journal of Obstetrics and Gynecology, 7, 41-50. https://doi.org/10.4236/ojog.2017.71005

[22] Ministère de la Santé et de la Lutte contre le SIDA. Enquête démographique et de Santé et à Indicateurs Multiples-Côte d'Ivoire, 2011-2012. Rapport Final, 202-203.

[23] Anorlu, R.I., Oluwole, A.A. and Abudu, O.O. (2006) Sociodemographic Factors in Anaemia in Pregnancy at Booking in Lagos, Nigeria. Journal of Obstetrics and Gynaecology, 26, 773-776. https://doi.org/10.1080/01443610600963846

[24] El Hafed, C., Dehah, M.O., Benzerroug, A. and El Ghadi, I.O. (2001) L’Anémie chez la femme en âge de procréer Wilaya du Gorgol (Mauritanie). Appui OMS, 23 p.

[25] Berger, J. (2004) Enrichissement des aliments en micronutriments: Elément d'une stratégie intégrée de lutte contre les carences en micronutriments, en particulier en fer, dans les pays en développement. Presses Universitaires de Ouagadougou, Paris, 563-575.

[26] Berger, J. and Dillon, J.C. (2002) Stratégies de contrôle de la carence en fer dans les pays en développement. Cahiers d'études et de recherches francophones/Santé, 12, $22-30$. 